\title{
A Concise Summary of policies in Relation to Well-Being of Children and Young People in Albania
}

\author{
Mcs. Eneida Zalli \\ Phd Candidate, Faculty of Education, University Aleksander Moisiu Durrës \\ Email: eneidazalli@hotmail.com \\ Phd. Eris Dhamo \\ Faculty of Social Sciences, University of Tirana \\ Email: eris_dhamo@yahoo.com
}

\section{Doi:10.5901/ajis.2016.v5n2p205}

\section{Abstract}

\begin{abstract}
The aim of this article is to display a reflection of how children's and youngsters wellbeing is viewed from a legal perspective including international framework and domestic ones. The Albanian government has drafted legal and institutional documents to protect the best interest of children and young people living in Albania. Some of these documents are included and explained in this paper. The Constitution of the Republic of Albania (1998) 1 is the highest law of the state and the main tool of governance. The Ministry of Social Welfare and Youth2 ensures the protection of the constitutional rights for every child. The Social Service in Albania3 is responsible for implementing policies, legislation and economic assistance and payment not only for children and youngsters but also for persons with disabilities and social services across the country. Other documents revised in this paper are Convention on the Rights of the Child4, the Universal Declaration of Human Rights5, the Convention on the Elimination of All Discrimination Against Women6, the European Convention for the Protection of Human Rights7, The Family Code (2003)8, Law no. 10347, dated 4.11.2010 "On protection of the rights of the child9, the National Strategy for Development and Integration 2007-2013, "Children Action Plan 2012 -2015 etc
\end{abstract}

The target of this article is to intrduce a reflection of how children's and youngsters wellbeing is viewed from a legal perspective including international framework and domestic ones. The Albanian government has drafted legal and institutional documents to protect the best interest of children and young people living in Albania. Some of these documents are included and explained in this paper.

The Constitution of the Republic of Albania (1998) ${ }^{10}$ is the highest law of the state and the main tool of governance. It has ruled that:

"Life is protected by law. Constitution of Albania considers the minor as subject to special protection (Article 54). "Children, adolescents, pregnant women and new mothers have the right to special protection by the State" (Article 54/1).

"Every child has the right to be protected from violence, abuse, exploitation and use for work, especially under the minimum age for child labor, which can harm the health, morals or endanger their life or normal development" (Article $54 / 3)$.

1 The constitution of the Republic of Albania (1998), Parliament adopted the Law 8417, dated 21.10.1998. https://www.constituteproject.org/constitution/Albania_2008.pdf

2 http://www.sociale.gov.al/al/ministria/misioni

${ }^{3}$ http://www.sherbimisocial.gov.al/

${ }^{4}$ http://femijet.gov.al/al/wp-content/uploads/2015/10/national-report-on-the-situation-of-childrens-rights-in-albania-2013-2014.pdf

${ }^{5}$ The Universal declaration of human rights, http://www.ohchr.org/EN/UDHR/Documents/UDHR_Translations/eng.pdf

${ }^{6}$ The Convention on the Elimination of All Discrimination Against Women, http://www.ohchr.org/Documents/Professionallnterest/cedaw.pdf

${ }^{7}$ http://www.echr.coe.int/Documents/Convention_ENG.pdf

${ }^{8}$ http://www.qbz.gov.al/botime/fletore_zyrtare/2012/PDF-2012/Kodi\%20i\%20familjes-2012.pdf

9 Law no. 10347, dated 4.11.2010 "On protection of the rights of the child http://www.unicef.org/albania/Action_Plan_Eng13.pdf

10 The constitution of the Republic of Albania (1998), Parliament adopted the Law 8417, dated 21.10.1998. https://www.constituteproject.org/constitution/Albania_2008.pdf 
Ministry of Social Welfare and Youth's mission is to ensure the constitutional rights for protection and social involvement, education and vocational training, secure and worthy employment, social security, social precautions and equal opportunities, to guarantee the participation of youth in the social life and to strengthen the cooperation with social partners, to guarantee freedom to religion, equality of religious communities, supports mutual understanding and religious tolerance. legislation:

Ministry of Youth and Social Wellbeig11 realises it's state's responsibility in these areas in accordance with relevant

- developes state's policies in the field of employment, education and vocational training;

- developes and monitors policies, legislation, activities relating to social security, and the process of coordinating social security schemes in other countries;

- developes policies that aim at the protection, promotion, integration and continuous improvement of social welfare for individuals, families and communities in need;

- developes policies for addressing issues of violence based on gender, abuse against children, women and other groups;

The Social Service ${ }^{12}$ in Albania is responsible for implementing policies, legislation and economic assistance, payment for persons with disabilities and social services across the country.

Although NGOs role has expanded in the recent years in providing social services, the state still remains the main factor for services for families and children in need. The current social protection system provides financial support to poor families (Financial Assistance Program), residential treatment for abandoned children with social problems and facilities for children as orphans.

From the evaluations that are done to investigate the service delivery for children is observed a large numbers of NGOs and various children's services mainly in the district of Tirana, Shkodra and Elbasan. Statistics from residential centers show that the majority of children are abandoned and come from families with social and economic problems located in central and northern Albania.

The network of Public Residential Care Institutions for Children consists of 9 public institutions and 13 nonresidential centers:

1. Orphan's Home from 0-3 years oldTirana, Durres, Shkodra, Korca, Vlora

2. Orphan's Home from 3-6 years old Shkoder

3. Orphan's Home from 6-15 years old in Tirana, Shkodra, Saranda

The services offered in the social care institutions are:

- Psycho-social services (counseling, group work, therapy, cultural activities, sports, integration, formation, entertainment, etc.).

- Health services (medical examinations, vaccinations, diet, etc.)

- Support Services (care, food, clothing, etc.)

- Educational services (education, qualification courses, teaching)

- Alternative Services

The deinstitutionalization and the provision of alternative services, such as that of guardianship, are the major objectives of the government policies in the area of social security for abandoned children, orphans or those in need. Guardianship Service has started piloting since 2011 in two municipalities (Tirana, Shkodra).

Convention on the Rights of the Child ${ }^{13}$ - has the duty to ensure the welfare of every child, "the child, because of his immaturity, physical and intellectual needs a special safeguards and care, including legal protection suitable, both before and after birth ". This statement, in its Article $3^{14}$ states that "In all actions concerning children, whether undertaken by public or private social welfare, courts of law, administrative authorities or legislative bodies, the best interests of the child should be a primary consideration "

Acts of the UN Universal Declaration of Human Rights, (1948) ${ }^{15}$, according to this declaration children as a special category should have a special protection. The United Nations reaffirmed that "childhood is entitled to care and support

\footnotetext{
11 http://www.sociale.gov.al/

12 http://www.sherbimisocial.gov.al/

${ }^{13}$ http://www.ohchr.org/Documents/Professionallnterest/crc.pdf

${ }^{14}$ www.unicef.org/crc/files/Rights_overview.pdf

${ }^{15}$ Acts of the UN Universal Declaration of Human Rights, (1948),
} 
special" this statement is intended to provide recognition and universal application of rights.

CEDAW- Convention on the Elimination of All Discrimination Against Women ${ }^{16}$ aims a direct protection of the rights of women and indirect protection for children's rights.

Acts of Council of Europe European Convention for the Protection of Human Rights ${ }^{17}$ signed by the member governments of the Council of Europe, under the protection and promotion of human rights and freedom for all, in its first Article states: "The Enforcement of all countries to respect human rights ". European Social Charter ${ }^{18}$ adopted by Law no. 8960 , dated $24.10 .2002^{19}$, provides that children and youngsters are entitled to special protection against physical and moral dangers to which are exposed.

The Family Code (2003) contains provisions governing the rights of children ${ }^{20}$. In the first part of it, the general principles, it states:

"Parents, authorities and courts, in their decisions and activities must have as a primary consideration the best interests of the child". (Article 2)

"... The state and society must provide the necessary support to families to keep their children at bay, to prevent the mistreatment and abandonment, as well as to maintain the stability of the family." (Article 3) "Every child, for the full and harmonious development of personality, has the right to grow in a familiar environment, in an atmosphere of happiness, love and understanding". (Article 5)

Law no. 10347, dated 4.11.2010 "On protection of the rights of the child"21, as well as the creation of the State Agency for Protection of Child Rights. It ensures all necessary measures to guarantee the life, welfare and development of children through a coordinated approach among the various actors working in the field of human rights and child protection. In his article 32 of this law defined "institutional mechanisms for the protection of children's rights", which in accordance with the field of activity of them are in the central and local level.

Mechanisms at the central level are:

a) The National Council for the Protection of the Rights of the Child22;

b) The Minister who coordinates the issues of protection of child rights;

c) National Agency for Protection of Child Rights ${ }^{23}$.

Mechanisms at local level are:

a) units for child rights in the regional council;

b) child protection unit in the municipality

Children Action Plan $2012-2015{ }^{24}$ approved by the Council of Ministers Decision no. 182 dated 13.03.2012. Objectives and measures of the Action Plan for Children 2012-2015 are grouped by children rights.

National Strategy for Development and Integration 2007-2013 25(NSDI), in which is crystallized the medium and long term vision of the development of the country based on an open and transparent process. In this document, issues related to child rights are addressed in the section: Social and Economic Development (2). Explicitly in the document is quoted the necessity for implementing the legislation for the promotion of children's rights and protection of life and health, and ensuring their education and development.

\section{References}

Kushtetuta e Republikës së Shqipërisë. (1998). Miratuar nga Parlamenti me Ligjin Nr.8417, Datë 21.10.1998.

Konventa mbi të Drejtat e Fëmijëve (KDF) Ratifikuar në 27 Shkurt të vitit 1992

Ligji nr.10347, date 04.11.2010, "Për Mbrojtjen e të Drejtave të Fëmijës"

Ligji nr. 9887, date 10.03.2008 "Mbi Mbrojtjen e të Dhënave Personale"

Ligji nr.9062, date 08.05.2003 " Kodi i Familjes"

\footnotetext{
16 The Convention on the Elimination of All Discrimination Against Women, http://www.ohchr.org/Documents/Professionallnterest/cedaw.pdf

17 http://www.echr.coe.int/Documents/Convention_ENG.pdf

${ }^{18}$ European Social Charter, http://lib.ohchr.org/HRBodies/UPR/Documents/Session6/AL/CoE_ALB_UPR_S06_2009_document5.pdf

${ }^{19} \mathrm{http}$ ://www.observator.org.al/wp-content/uploads/2014/01/Policy_Study_Children_in_street_situation_23-January_2014.pdf

20 http://www.qbz.gov.al/botime/fletore_zyrtare/2012/PDF-2012/Kodi\%20i\%20familjes-2012.pdf

${ }^{21}$ Law no. 10347, dated 4.11.2010 "On protection of the rights of the child",

${ }^{22}$ http://www.crca.al/sites/default/files/publications/Law\%20on\%20children's\%20rights\%20in\%20Albania\%202010.pdf

23 National Agency for Protection of Child Rights.

24 http://www.unicef.org/albania/Action_Plan_Eng13.pdf

${ }^{25} \mathrm{http}: / /$ www.unicef.org
} 
National Strategy for Development and Integration 2007-2013

Children Action Plan 2012 -2015

Convention on the Elimination of All Discrimination Against Women

http://www.sociale.gov.al/

http://www.sherbimisocial.gov.al/

http://www.crca.al/sites/default/files/publications/Law\%20on\%20children's\%20rights\%20in\%20Albania\%202010.pdf

National Agency for Protection of Child Rights.

http://www.unicef.org/albania/Action_Plan_Eng13.pdf

http://www.unicef.org

The Convention on the Elimination of All Discrimination Against Women, http://www.ohchr.org/Documents/Professionallnterest/cedaw.pdf http://www.echr.coe.int/Documents/Convention_ENG.pdf

European Social Charter, http://lib.ohchr.org/HRBodies/UPR/Documents/Session6/AL/CoE_ALB_UPR_S06_2009_document5.pdf http://www.observator.org.al/wp-content/uploads/2014/01/Policy_Study_Children_in_street_situation_23-January_2014.pdf http://www.qbz.gov.al/botime/fletore_zyrtare/2012/PDF-2012/Kodi\%20i\%20familjes-2012.pdf

Law no. 10347, dated 4.11.2010 "On protection of the rights of the child",

The constitution of the Republic of Albania (1998), Parliament adopted the Law 8417, dated 21.10.1998. https://www.constituteproject.org/constitution/Albania_2008.pdf

http://www.sociale.gov.al/al/ministria/misioni

http://www.sherbimisocial.gov.al

http://femijet.gov.al/al/wp-content/uploads/2015/10/national-report-on-the-situation-of-childrens-rights-in-albania-2013-2014.pdf

The Universal declaration of human rights, http://www.ohchr.org/EN/UDHR/Documents/UDHR_Translations/eng.pdf

The Convention on the Elimination of All Discrimination Against Women, http://www.ohchr.org/Documents/Professionallnterest/cedaw.pdf 